\title{
Tax knowledge for the digital economy
}

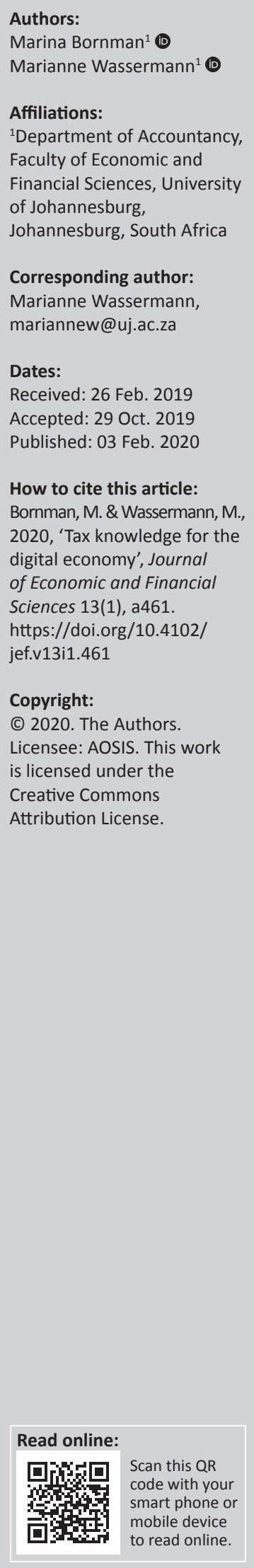

Orientation: Because of the digital economy, taxpayers have access to new income streams. These virtual transactions have taxation consequences, and therefore taxpayers need specialised taxation knowledge to understand their tax obligations and act in a tax compliant manner.

Research purpose: The aim of this article was to identify the unique tax knowledge requirements for individuals functioning in the digital economy by systematically reviewing literature on the tax challenges arising from this new economy. Applying a conceptual framework of tax knowledge, these knowledge requirements were categorised as either general, procedural or legal. By identifying these requirements, it was possible to point out the risks within these categories that may cause obstacles to individuals to act fully tax compliant.

Motivation for the study: Understanding the different knowledge requirements of taxpayers may assist tax authorities to identify the tax compliance risks of these taxpayers in their capacity as individuals functioning in the digital economy.

Research approach/design and method: A qualitative approach was used in the study through a thematic search of appropriate literature such as articles, reports, blogs and media releases. These documents were systematically reviewed to identify the knowledge requirements for individual taxpayers functioning in the digital economy.

Main findings: The findings suggest that there are specific tax knowledge requirements in different areas that must be in place to ensure tax compliance in the digital economy. Any shortcomings in these areas of knowledge create the risk of non-compliance for individuals functioning in the digital economy.

Practical/managerial implications: Taxpayers and tax authorities alike should take note of the risk areas identified in each area of knowledge (general, procedural and legal) and devise strategies to deal with taxation issues arising from transactions in the digital economy.

Contribution/value-add: This study applied a tax knowledge framework and identified the general, procedural and legal tax knowledge requirements of individuals functioning in the digital economy. The study also pointed out associated compliance risks, which may assist tax authorities to target strategies for improving taxpayer knowledge in these three areas.

Keywords: digital economy; conceptual framework; tax compliance; tax knowledge.

\section{Introduction}

Which one of us can go without looking at our mobile phone, electronic device or computer for 1 day, or even $1 \mathrm{~h}$ ? With just the press of a button, one is instantly connected to the digital economy. The rise of the digital economy in the last 20 years means that 'digitalisation, that is, the growing use of information and communication technologies (ICT) [is] in every area of life [and] has profoundly shifted society, business and personal lives' (Vuori, Helander \& Okkonen 2019:237). Babu (n.d.) summarises Tapscott's definition of digital economy as:

[I]nformation in digital form, facilitated by the digital devices (that) allow the free movement of vast amounts of information in the shortest time possible between people in different parts of the world. (p. 1)

The digital economy (also referred to as the 'new economy') is further defined by Carlsson (2004) as being:

...[A]bout dynamics, not static efficiency. It is more about new activities and products than about higher productivity. What is really new in the New Economy is the proliferation of the use of the Internet, a new level and form of connectivity among multiple heterogeneous ideas and actors, giving rise to a vast new range of combinations. There are some measurable effects on productivity and efficiency, but the more important long-run effects are beyond measurement. (p. 245) 
Hojeghan and Esfangareh (2011) specify that the digital economy is where providers and customers transact through the Internet with electronic goods and services only. These goods and services are produced and traded solely through the Internet and web-based technology. Digital technology also has an impact on communication, as digital communication is the most effective and convenient method (Nickitas 2019).

The use of electronic devices and the Internet are changing the nature of products and services, how these products are manufactured and the way the products and services are marketed and sold (Haltiwanger \& Jarmin 2002). The Internet also gives taxpayers access to new income streams through virtual transactions. These transactions can be concluded in the form of 'real money' or virtual currencies (Switzer \& Switzer 2014). Even though these transactions are virtual, take place in the digital economy or are settled in virtual currencies, they still have taxation consequences for participants to the transactions. Taxpayers therefore need taxation knowledge to be able to account for these transactions on their tax returns. Often, the tax consequences of these transactions are neither identified nor recorded for income tax or sales taxes (Cockfield 2002). As stated by Basu (2001), the taxation of digital transactions can be complicated: the server on which the transaction is processed, the city from where the goods are shipped and the destination of the goods are all at different locations - then where will the transaction be taxed? The participants to the digital transactions will therefore need some tax knowledge to identify where and when tax consequences will be triggered. A lack of such knowledge may lead to tax non-compliance for individuals living in the digital economy.

In addition to transactions performed through the Internet and web-based technology in the digital economy, Vuori et al. (2019:237) add that digitalisation 'enables easier, faster and more affordable interaction among people, companies and governments without the restraints of time and presence'. Goncalves, Oliveira and Cruz-Jesus (2018) explain that these interactions necessitate the use of different types of media that require digital skills in addition to basic reading and writing abilities. Governments have also been extending their services through Internet technology and, in so doing, have increased the effectiveness, efficiency and convenience of interactions with citizens (Chen et al. 2015). The Organisation for Economic Co-operation and Development (OECD) reports that tax authorities are increasingly developing digital applications to support tax activities such as paying, filing and enquiry (OECD 2017a). It can thus be argued that taxpayers may also benefit from having the digital knowledge and skill to effectively interact with the tax authorities in the digital environment.

\section{Tax knowledge and tax compliance}

Academic literature shows mixed results on the relationship between tax knowledge and tax compliance. While the importance of tax knowledge for tax compliant behaviour has been shown to be essential by some researchers, others find a weak correlation between tax knowledge and attitudes towards tax compliance (Cvrlje 2015). An early study by Eriksen and Fallan (1996) supports the principle that attitudes towards tax compliance can be improved through better tax knowledge. Other empirical studies finding a significant positive effect of tax knowledge on tax compliance are those of Ali and Ahmad (2014), Andreas and Savitri (2015), Mukhlis, Utomo and Soesetio (2015), Niemirowski, Baldwin and Wearing (2003), Oladipupo and Obazee (2016), Palil (2010), Palil and Mustapa (2011) and Saad (2014).

One of the complications in interpreting evidence on the role of tax knowledge in tax compliance is the fact that different studies use different interpretations of what tax knowledge encompasses. They also use different measures to determine individuals' tax knowledge. Some examples of how tax knowledge can be defined are described as follows:

- Palil and Mustapa (2011) divide tax knowledge into seven sub-categories, including taxpayers' responsibilities and rights, specific income and deduction rules and awareness of penalties.

- Mukhlis et al. (2015) merely propose tax knowledge to be the public's understanding of tax and certain matters relating to the taxation system.

- Oladipupo and Obazee (2016:2) state that tax knowledge is the 'level of awareness or sensitivity of the taxpayers to tax legislation'.

In arriving at a comprehensive explanation of the concept of tax knowledge, some efforts by tax authorities to educate citizens about their tax responsibilities are studied in the paragraphs below and the objectives of such efforts are identified. Based on these objectives, elements of tax knowledge may then be recognised.

Worldwide, tax authorities have realised that tax knowledge will lead to better tax compliance. Consequently, they have embarked on various taxpayer education projects to improve tax knowledge (OECD 2015a). The OECD has combined these projects in a 'Global source book on taxpayer education' (OECD 2015a). This publication notes that it is difficult to change perceptions of older taxpayers, and therefore many countries like Rwanda, Jamaica, Kenya, Mauritius, Morocco and Peru start their taxpayer education projects at school level (OECD 2015a; Rwanda Revenue Authority 2019). Malaysia and Costa Rica try to make tax fun with tax speech competitions and junior tax offices to teach children the tax cycle, starting with the government's expenditure and how to use the collected taxes (OECD 2015a). Mexico and El Salvador seek to improve the tax culture of students. In Brazil and Burundi, students are trained to assist low-income taxpayers and small businesses with their tax affairs for no payment. Small informal businesses and rural areas are also being targeted in Korea, Mozambique and South Africa, with special classes, campaigns and mobile units (OECD 2015a).

The OECD (2015a) further reports that many countries acknowledge that the new technological tax filing era requires 
new training. Therefore, Colombia, Estonia, El Salvador and Chile provide online training and web portals for students and educators. Uruguay even has a special 'Plan Ceibal' which aims to provide every child with electronic tax activities on a laptop. Many countries such as India and South Africa air television advertisements during their tax seasons, while Nigeria promotes the payment of taxes through a soap opera on television (Alakam 2013; Income Tax Department 2019; Sharp 2015).

In Zambia, where only a few people own televisions, a weekly radio programme is aired every Wednesday where tax matters, including changes in the legislation, are discussed (OECD 2015a). The Mauritius Revenue Authority takes technology even further by using a social networking site (Twitter) to inform taxpayers of changes in legislation (Mauritius Revenue Authority n.d.).

Some countries seek to build a culture of tax compliance by raising awareness of citizens' tax obligations and inspiring citizens to pay their taxes (Faizan 2018; Gaber \& Gruevski 2018; OECD 2015a; Rwanda Revenue Authority 2018). For example, Bangladesh, Rwanda and Senegal have national tax days. In Rwanda, the best taxpayers are rewarded by the president on this day (Rwanda Revenue Authority 2018). In Guatemala, residents can obtain information at tax stands during the annual citizen culture festival (OECD 2015a). In South Africa, two media companies have two independent tax days where employees of the South African Revenue Service (SARS) assist the companies' employees with tax issues. Almost 6 million people are reached by these two initiatives (OECD 2015a).

Countries like Bhutan not only build a culture of tax compliance but also conduct training to encourage taxpayers to take part in the tax payment process (OECD 2015a). In South Africa, SARS aired various advertisements to show how tax money is used for good to inspire taxpayers to pay their taxes. One example is where a man receives a successful eye operation and is able to see (Mbatha 2015).

From the above, it is clear that the following main objectives form the basis of taxpayer education:

- creating an environment that will lead to the youth being tax literate

- educating taxpayers about how tax returns should be submitted

- providing updates on changes in taxation legislation

- encouraging and inspiring residents to pay their taxes.

Taxpayer education seemingly pursues three dimensions of knowledge about taxes, namely, a dimension of general awareness of why and when we need to pay taxes, a dimension of knowing how to interact with tax authorities and a dimension of knowing how we are taxed. There appears to be value in identifying the knowledge requirements of taxpayers in specific contexts or industries, as this may assist tax authorities in educating taxpayers.
Bornman and Ramutumbu (2019) proposed a framework of tax knowledge that provides a structured approach for assessing tax knowledge requirements in various contexts as a factor influencing tax compliance. The framework suggests that tax knowledge is discernible in three categories: (1) general tax knowledge, (2) procedural tax knowledge and (3) legal tax knowledge. This study applies this framework to identify and categorise the unique tax knowledge requirements of individuals functioning in the digital economy. It is suggested that an identification of knowledge requirements in a specific industry may not only assist tax authorities in developing targeted education strategies but also highlight risks of non-compliance resulting from gaps in tax knowledge of the participants to that industry.

This article is structured as follows. In the next sections, the objective and method are presented, followed by a brief review and rationalisation of the conceptual framework. Thereafter, the results of the study are presented, together with the tax knowledge requirements and problem areas for taxpayers in the digital economy. The risks relating to tax knowledge in the digital economy are then highlighted, followed by the study conclusion.

\section{Objectives}

The first objective of this study is to identify the tax knowledge requirements of individuals functioning in the digital economy and to categorise these requirements as general, procedural or legal. The second objective is to point out risk areas in terms of knowledge requirements that may impede tax compliance among individual taxpayers. An awareness of these risk areas may assist tax authorities in devising targeted strategies for improving taxpayer knowledge for the digital economy on different levels.

\section{Method}

A qualitative approach was used in the study by means of a thematic search of appropriate literature. The OECD comparative information series (OECD 2015b, 2017b) on tax administration was largely used to report on the digitalisation of the interaction between taxpayer and tax authority. Other literature, in the form of articles, reports, blogs and media releases, was sourced using keywords such as 'tax knowledge', 'digital economy', 'digital disruption', 'electronic commerce', 'e-commerce', 'tax awareness' and 'tax literacy' on academic databases (Scopus, Taylor \& Francis, EBSCOhost and OECD iLibrary) to find information on tax challenges resulting from the digital economy. Refined searches were performed within results to limit the subject field to 'tax' or 'accounting'. The result lists were scanned for relevance according to inclusion criteria, and documents were then either retained or rejected. The inclusion criteria specified that the article should contain information on economic transactions that are facilitated through the Internet or information on the digitalisation of communication between taxpayer and tax authority (or tax administration). Data were collected during January to October 2018, and new documents were added until theoretical saturation was reached in terms 
of the broad themes identified for further analysis. This process of data collection and sampling can be described as theoretical sampling, which Saunders, Lewis and Thornhill (2012) describe as a form of purposive sampling designed to pursue theoretical lines of enquiry rather than to achieve representativeness.

The documents were then systematically reviewed to find evidence of transactions or situations in the digital economy (or themes) which could require specific tax knowledge. The broad themes that were identified included virtual transactions and currency, Internet-based transactions, online platforms, tax administration and digitalisation of accounting records. Three codes of general knowledge, procedural knowledge and legal knowledge were used to categorise text according to themes identified in the data. This can be termed an interpretative approach, whereby predefined codes are assigned to portions of text according to the meaning attached to it by the researcher. Saunders et al. (2012) indicate that an interpretative approach involves subjective meaning-making of the details of a situation and the reality behind those details.

A limitation of this study is that it is not an exhaustive investigation but rather an exploratory account of new tax knowledge requirements, resulting from new situations and transactions because of the digitalisation of the economy. Given the rapidly evolving nature of the digital economy, new transactions and events may come to light on a continuous basis, which may result in additional tax knowledge requirements that are not recognised in this study.

\section{A framework for tax knowledge The need for a conceptual framework of tax knowledge}

Bornman and Ramutumbu (2019) contend that there is no uniform meaning of the concept of 'tax knowledge', and there is little reference to the different elements of tax knowledge despite its importance in influencing tax compliance. Bornman and Ramutumbu (2019) examined various studies on the effect of tax knowledge on compliance, and found that authors recognise elements of tax knowledge as, for example, 'understanding laws', 'applying laws', 'reporting tax information' and 'submitting returns'. To illustrate this, findings by Palil (2010) and Saad (2014) suggest that there is a positive relationship between taxpayers' ability to understand and apply tax laws and regulations and their ability to comply. Kamleitner, Korunka and Kirchler (2012) concur that the lack of understanding of complex requirements for reporting and submitting tax returns may result in non-compliance with tax laws.

Bornman and Ramutumbu (2019) further argue that different elements of tax knowledge are necessary to improve a taxpayer's ability to comply. They assert that tax knowledge can be viewed as having three elements, namely, legal, procedural and general. Their study proposes a conceptual framework of tax knowledge, as shown in Figure 1.
The elements of tax knowledge are briefly discussed below under the headings general tax knowledge, procedural tax knowledge and legal tax knowledge.

\section{General tax knowledge}

General tax knowledge relates to having a fiscal awareness, which Bornman and Ramutumbu (2019) equate to Kirchler's (2007:31) interpretation of 'ordinary people's understanding of taxation'. Cullis and Lewis (1997:310) talk about a 'fiscal consciousness', referring to peoples' recognition of taxes as contributing to the public budget. Buehler (1940:246) asserts that a:

[C]onsciousness [or awareness] of taxation is a necessary element of good citizenship, but the understanding of taxation must be broadened to include an understanding of public spending and borrowing as they are related to taxation. (p. 246)

Kamil (2015) proposes that awareness includes recognition of taxpayers' attitude towards a willingness to pay taxes. This notion is echoed by Bornman and Ramutumbu (2019) in their view of tax morality as an element of tax awareness, where tax morality refers to an intrinsic willingness to pay taxes. Wilson, Abraham and Mason (2014) observe that 'awareness' is a pre-condition to being literate. Tax awareness is thus an essential element of the tax knowledge required to behave in a tax compliant manner. This is confirmed by Hastuti (2014), who explains that tax is inevitable for most people, and therefore tax awareness is the cornerstone of tax compliance. His suggestion that tax awareness is the ability of taxpayers to take ownership of their tax calculations, payments and reporting may be of note. In other words, tax awareness includes knowing when you are liable for tax and understanding how your decision to be compliant or not will influence your financial position.

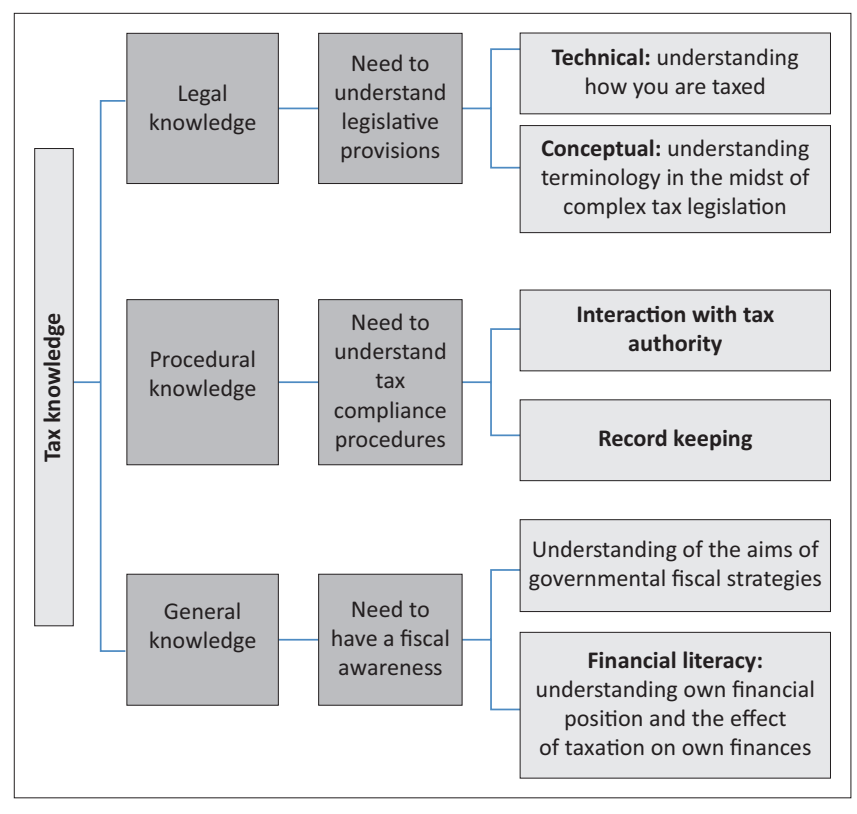

Source: Bornman, M. \& Ramutumbu, P., 2019, 'A conceptual framework of taxpayer knowledge', Meditari Accountancy Research 27(6), 823-839.

FIGURE 1: A conceptual framework of tax knowledge. 
In this study, the understanding of general tax knowledge is suggested to include the following:

- Having a fiscal awareness or understanding of why taxes are paid, as per Cullis and Lewis (1997) and (Buehler 1940).

- Understanding who should take ownership of being liable for tax calculations, payments and reporting, as per Hastuti (2014), including an understanding of the tax consequences of the decision made.

\section{Procedural tax knowledge}

Tallaha, Shukor and Hassan (2014) explain that procedural knowledge refers to the skills and resources to interact with tax authorities and have one's tax records in order. Bornman and Ramutumbu (2019) maintain that taxpayers need to be aware of tax processes and their responsibility to adhere to tax laws. Therefore, for example, this would refer to how and when to file tax returns and supply information to the tax authorities. Oladipupo and Obazee (2016) add that this involves an understanding of tax systems and processes, knowing the tax requirements, being aware when a person will be tax compliant and adhering to timelines. Tallaha et al. (2014) point out that the ability to use an electronic tool to submit a tax return does not necessarily mean that the returns are complete or filed correctly. Even though taxpayers are confident with the procedures, it does not mean they are applying the legal tax knowledge. Taxpayers therefore still need a certain level of legal tax knowledge to ensure that they are tax compliant.

\section{Legal tax knowledge}

Legal knowledge refers to an understanding of how one is taxed (Tallaha et al. 2014) and has two dimensions: (1) understanding legal terms and legislation (knowing that something is taxable) and (2) the ability to apply the legal knowledge to specific situations to be able to calculate the tax effect (knowing how) (Lai et al. 2013). Bornman and Ramutumbu (2019) specify that legal tax knowledge includes a 'broad understanding of legal terminologies' and 'the ability to apply specific rules and regulations in order to accurately determine [one's] tax liability'.

\section{Tax knowledge requirements in the digital economy}

The analysis that follows aims to determine whether there are unique requirements for 'tax knowledge' in the digital economy categorised as general, procedural or legal tax knowledge.

\section{General tax knowledge}

Based on Bornman and Ramutumbu's (2019) framework, it was proposed that general tax knowledge includes an awareness of (1) why taxes should be paid and (2) who is liable for paying taxes and understanding the consequences of your decision to be compliant or not. There are no evidence to the authors' knowledge to support that the 'why taxes should be paid' dimension would be different in a digital economy as opposed to an economy without digital transactions. This study therefore focuses only on the element of who is liable for a tax as a result of operations in the digital economy. It is also suggested that the consequences of the decision to be compliant or not will be similar in any industry and therefore is not addressed in this study.

The OECD (2019) suggests that taxpayer education may improve effective self-reporting among online platform users. Uncertainty among online platform users about their tax liabilities arises because of challenges over determining the correct employment status, being unaware of relevant income thresholds and understanding whether an activity is carried on as a business. The following remarks from various authors in the context of the sharing economy ${ }^{1}$ illustrate the need to understand who is liable for paying taxes. Bornman and Wessels (2019) observe that many operators in the sharing economy manage to 'slip through the tax cracks'. Similarly, Frenken and Schor (2017:8) note that many homesharing operators are 'not even aware that taxes should be paid', while Deards (2017:249) points out that the sharing economy 'brings into the market a large number of individuals who are not otherwise business taxpayers', who may be confronted with unexpected tax issues. Thorne and Quinn (2017:74) add that transactions in the sharing economy are 'often brief, relatively private, and singular in nature', or individuals providing services through an online platform may regard such activities as hobbies or recreational activities (Deards 2017). This could indicate that these individuals deem such transactions as not taxable.

In addition to understanding their own liability for declaring income generated by using online platforms, liabilities for other taxes may also arise. For example, many countries levy a tourism tax on holiday accommodation (Zale 2016), and this may place an additional obligation on home-sharing operators to be aware of their role to collect and remit these taxes to appropriate authorities.

A lack of awareness of tax obligations may occur in many other situations where providers and customers transact through the Internet, for example, income generated from a YouTube channel, mining or trading in virtual currencies, online advertising and sales, and providing online payment services. It may be that operating outside the traditional 'four walls' of business premises creates the perception that income is private and need not be declared for tax purposes. It is thus argued that the element of 'who is liable for paying taxes' is a valid element of general tax knowledge for operators in the digital economy.

\section{Procedural knowledge}

Procedural knowledge refers to the skills and resources required to interact with tax authorities and having one's tax records in order. There are thus two aspects to investigate here: (1) the digitalisation of tax administration (affecting taxpayers' 1.The sharing economy can be defined as 'online platforms that help people share access to assets, resources, time and skills' (Wosskow 2014:14). 
interaction with authorities) and (2) the digitalisation of processes to record transactions and maintain records for tax purposes.

\section{Tax administration}

According to the OECD's (2015b:243) comparative information on tax administration in advanced and emerging economies, 'many revenue bodies have taken steps to exploit the use of modern computer technologies to transform their operations'. The report observes that the reason for this is obvious, given the exponential growth in the use of technology by citizens and businesses (OECD 2015b). Offering online services to address tax obligations should therefore be both easy and attractive for taxpayers to use.

The OECD (2015b) report provides internationally comparative data on aspects of tax systems and their administration in 56 advanced and emerging economies up to the end of the 2013 fiscal year. The findings suggest that the main types of online services include the following:

- provision of a comprehensive range of tax and other information, forms and calculators on websites

- electronic filing of tax returns for the major taxes

- the provision of fully and/or partially completed or prefilled tax returns for personal income tax

- a range of electronic payment options for all taxes

- access to secure, detailed personal taxpayer information via online portals

- call centres using modern telephony facilities to provide more accessible phone inquiry services (OECD 2015b).

In addition to the above, the OECD (2015b) report mentions a number of possibilities for enhancing taxpayer services:

- value-added tax (VAT) e-invoicing systems to support businesses and the revenue body's administration of VAT

- automating data capture from third parties (e.g. from employers and financial bodies) that are required for routine tax administration processes (e.g. verification and pre-filling of tax returns)

- digital mailbox (e.g. notices of assessment and taxpayer accounts) that is sent to taxpayers electronically via a secure portal.

What is notable is that almost $60 \%$ of the revenue bodies surveyed report that in 2013 more than $70 \%$ of their personal taxpayers used e-filing for their tax returns (either by themselves or via tax professionals) (OECD 2015b). For 2014 and 2015, the OECD reports that two-thirds of personal income tax return filers submitted their returns online (this was for 35 tax jurisdictions surveyed) (OECD 2017b).

The above facts suggest that information and communication technology skills (ICT skills) may enhance efficient interaction between taxpayer and their tax authority. It is therefore concerning to note that according to an OECD (2016) report entitled 'Skills for a digital world', over $40 \%$ of workers using office software every day do not seem to have sufficient skills to use them effectively (this figure is based on the research performed across 18 developed countries). The OECD (2016) report refers to 'digital literacy' as the ability to read and navigate digital content autonomously. The report argues that the performance of 15-year-old students in digital literacy was positively correlated with their performance in reading. It is further suggested that navigational skills (i.e. the ability to 'click' correctly when navigating a webpage) have more to do with the ability to regulate and monitor cognitive processes or with spatial reasoning than with the mere technical aspect of browsing. The report confirms the importance of foundational skills as a basis for the acquisition of the skills that will increasingly be required in the digital economy. The OECD (2016:12) report concludes that 'reading and writing skills become increasingly relevant to fully grasp the benefits of technology rich societies'.

Often, the assumption is made that young people are naturally or automatically digitally literate, but interestingly, according to the OECD (2016:23) report, evidence shows that 'young people entering the workplace make the least use of information processing skills, including ICT skills, in comparison with prime age workers'. Macklin (2008) argues that students acquire ICT skills mainly through use, while De Wit, Heerwegh and Verhoeven (2014) maintain that access to computers and the Internet are naturally important for acquiring ICT skills. A study on the drivers of ICT acceptance on an individual level by Goncalves et al. (2018) finds that individuals consider resources and support to be important to ICT acceptance. They also show that once ICT use becomes routine, individuals are more likely to use it. However, Sandhu, Damodaran and Ramondt (2013) found that fear of using a computer and memory problems, among other factors, are barriers to acquiring ICT skills in older people. Furthermore, proficiency in ICT facilitates practice, while practice reinforces proficiency; in other words, the ICT skills of an individual will deteriorate if not used. In the context of fulfilling one's tax obligations, this could imply that simply because an individual did e-filing once, they may not be able to get it right next time. From the above discussion, it follows that the ability to autonomously read and navigate digital content (i.e. digital literacy) is an essential component of the procedural knowledge required by individual taxpayers to interact effectively with tax authorities.

Another aspect of procedural knowledge has to do with taxpayers' ability to record transactions electronically and maintain records of the amounts they have used in their tax returns, including those they have done through e-filing. According to SARS (2018), these records should be kept for prescribed times and may be kept in digital format.

\section{Digital record-keeping}

Because of an increase in the use of digital records and the storing of traditional paper records in digital format, there is a demand for new skills to be able to understand the digital processes to store information (OECD 2016). The change in the way information can be stored digitally is exponential; however, these new ways of storage also 
create material risks. If not stored correctly, information can be lost (Rothenberg 1995).

The World Bank (2015) has identified several areas of digital competence that could assist with correct record-keeping. The following competencies are applicable to tax knowledge requirements:

- Information: identify, locate, retrieve, store, organise and analyse digital information, judge whether it is relevant, which tax period it relates to and the purpose of the information.

- Content creation: create and edit new content and integrate and re-elaborate previous knowledge and content. A good example is to correctly edit programmes to take changes in tax rates into account.

- Problem-solving: identify digital needs and resources, make informed decisions on the most appropriate tools accordingly and solve conceptual problems through digital means. This could relate to obtaining tax asset registers, identifying new assets acquired or assets disposed of and preparing information for taxation audits (World Bank 2015).

The competencies pointed out above are needed by taxpayers to adhere to digital tax record requirements. The discussion above highlights the fact that there are distinctive knowledge requirements on a procedural level necessary to make informed decisions about tax obligations when operating in the digital economy.

The next section discusses specific legal knowledge requirements, which are unique to the digital economy.

\section{Legal knowledge}

Legal knowledge refers to an understanding of what tax laws mean (Oladipupo \& Obazee 2016) and knowing how to apply tax rules to a particular transaction. The digital economy poses unique challenges to tax authorities as well as taxpayers, as evident from an OECD (2017a) report on the tax challenges of digitalisation. Although the report focuses on multi-national corporations and cross-border transactions, it is clear that transactions such as providing digital goods and services, selling goods online and providing services via a website require unique legal rules and procedures.

An individual operating in the digital economy may be transacting in a business enhanced by the Internet such as home-sharing (e.g. Airbnb), ride-sharing (e.g. Uber) or providing services to clients via a website (e.g. connecting tutors with pupils or house cleaners with home owners) (Nellen 2015). Individuals may also have made purchases online, sold goods, information or services online, generated income from online games or gambling, cashed virtual money, generated income from a personal blog or YouTube or from their own digital assets (Nellen 2015).

Bornman and Wessels (2019) examined studies on the sharing economy and identified three main legal knowledge requirements for the individual operating in the sharing economy. Firstly, they found that the uncertainty around employee or contractor status was frequently documented especially in relation to Uber (or other ride-sharing platforms). Secondly, the registration, collection and remittance of transient occupancy tax in the case of home-sharing platforms were a dominant theme throughout the home-sharing literature. Thirdly, the use of personal assets for commercial purposes and the accompanying tax deductibility of expenses were another recurring theme in the literature.

Deards (2017) mentions more tax consequences arising from home-sharing transactions: (1) the possibility that part of the capital gains tax principal place of residence exemption will be lost when the taxpayer sells his primary residence; (2) when home-sharing expands to the offering of conference rooms and offices, it may attract consumption taxes such as VAT or general sales tax (GST); and (3) there may be other taxes of which a provider of home-sharing should be aware. Deards (2017:251) reports on a Tasmanian case where the Office of State Revenue is reported to have sought recovery of land tax from a couple renting their home through Airbnb'. Zietsman (2017) further demonstrates the complexity of valuing for income tax purposes, the receipt of a 'right of accommodation' with respect to home-swapping (another type of home-sharing platform).

With respect to ride-sharing, Deards (2017) argues that the most significant issue with respect to taxation and ride-sharing, in the context of consumption taxes, is whether the provision of ride-sharing is a supply for GST (or VAT) purposes of 'taxi travel'.

Another type of transaction in the digital economy to consider is the provision of digital goods and services. Included in digital goods are games, music, documents, software and even ringtones. Examples of digital services are online gaming, communication services, website hosting and virtual worlds. With respect to the income from the provision of such goods and services, the individual will have to consider tax legislation to determine the source of the income and where the transaction should be subject to income tax. Sales taxes have to be considered as well. Expenses incurred to provide the goods and services must be measured against deduction criteria to determine whether it can be deducted for taxation purposes as incurred or whether it will only be deducted over a number of years because of it being of a capital nature or for research purposes (Nellen 2015).

To further complicate matters, tax legislation differs from country to country with regard to rules for deductibility of expenses and allowances on capital assets (Olivier \& Honiball 2011). Even though the individual may have tax knowledge regarding their country of residence, there may be tax consequences in another country, and the individual should then know whether there are any double tax treaties or taxation provisions available to grant relief against double tax. 
Nellen (2015) notes that in transactions concluded in virtual currencies, there are three levels for which the knowledge requirements should be considered: (1) mining the virtual currency, (2) using the virtual currency and (3) holding the virtual currency. The mining of virtual currencies might be seen as a trade, causing the profits to be subject to income tax (Akins, Chapman \& Gordon 2014; Bal 2015). Virtual currency is seen as an asset and may have income and/or sales tax consequences if sold or donated (Akins et al. 2014; Bal 2015). If used as a form of payment, the transaction will be subject to the normal tax rules. Merely holding the virtual currency will not have immediate tax consequences, but it will be included in the individual's estate upon death or liquidation (Nellen 2015).

Some of these challenges have been addressed in the OECD's Base Erosion and Profit Shifting Project (OECD 2015c). The OECD has issued various reports, the latest being the 2018 interim report entitled 'Tax challenges arising from digitalisation' to assist taxpayers and tax collectors with detecting and taxing transactions in the digital economy.

This section pointed out specific transactions in the digital economy, such as services provided in the sharing economy, online sales and purchases and virtual currencies. These themes provide evidence that there are specific legal knowledge requirements that co-determine the tax knowledge of an individual functioning in the digital economy.

\section{Risks identified}

The three areas of general, procedural and legal tax knowledge may pose obstacles, which hinder the tax compliance of individuals. These obstacles are discussed in the following sections.

\section{General tax knowledge}

Frenken and Schor's (2017:74) observation that many homesharing operators are 'not even aware that taxes should be paid' implies that there is a risk of non-compliance by these individuals. It was suggested earlier that these business operators might regard transactions in the sharing economy as 'brief, singular and private' and therefore not taxable. Similarly, income-generating activities conducted through the Internet, for example, income from a YouTube channel, may be perceived as private in nature and individuals may think it does not have to be declared for tax purposes. Furthermore, it can be logically inferred that individuals who are not aware of 'who is liable for paying taxes' may also not be aware of 'how' these transactions and resulting tax liabilities should be reported.

\section{Procedural knowledge}

With respect to tax administration, it was found that taxpayers might be lacking ICT knowledge and skills as well as reading and writing skills. The OECD (2017b) comparative survey on tax administration reports that only two out of three personal income tax return filers filed their returns electronically (OECD 2017b). South African Revenue Service also highlights in its 2017 annual report that taxpayers' fear of making mistakes, being unable to upload supporting documents, fear of fraud or scams and the lack of access to the Internet are factors that contribute to their reluctance to use e-filing. The OECD (2017b) provides further evidence of inadequate ICT knowledge and skills in its comparative survey on tax administration that reveals that almost $12 \%$ of taxpayers still pay their taxes in person at the tax administration office rather than using online payment or agency services.

The risk identified here is that taxpayers who have insufficient knowledge of how to use online portals may experience this as a stumbling block in their interactions with the tax authority. Some countries use their websites to provide a range of online content to support and assist taxpayers. For example, the Australian Taxation Office (ATO) website provides cash flow management tools and self-help tools to assist taxpayers to manage their tax debts (OECD 2017b); however, tax authorities need to be aware that not all taxpayers are able to use web-based technologies.

The other aspect of procedural tax knowledge that poses a risk for tax compliance is related to record-keeping for tax purposes. When records are kept in digital format, there is a risk that the information may get lost if the individual does not have the necessary competencies to store and retrieve the records. Individuals may also not know which records to keep and which of those records to produce when submitting their return (Rothenberg 1995; Tallaha et al. 2014).

Although some countries develop creative and innovative working prototypes such as record-keeping and expensetracking mobile apps (e.g. Singapore and Finland) (OECD $2017 \mathrm{~b}$ ), these measures will only be useful if taxpayers are made aware of these applications and are then educated and supported to use them optimally.

\section{Legal knowledge}

In the sharing economy, there are various legal tax-related pitfalls such as employee or contractor status and the various compliance rules associated with each of these that need to be observed. The collection, disclosure and payment of occupancy taxes to the relative authorities create another risk as these payments are sometimes in cash and never paid over to the authorities. Lastly, the tax treatment of personal assets and deductibility of other expenses create problems of overor under-declaration if the taxpayer does not have the knowledge to determine whether these expenses qualify for tax deductions or capital allowances.

Other compliance risks arise from the provision of digital goods and services. These include the lack of knowledge of the source and tax location of the income, the type of tax applicable to the transaction or the tax treatment of expenditure and allowances on capital assets (including 
research development costs). In cases where income from transactions is subject to tax in the country of source as well as in the country of residence, the problem of double tax can only be solved if the taxpayer knows there is double tax and what the possible remedies are.

Transactions in virtual currencies create two possible dilemmas. The first is that the taxpayer needs to be aware that even though these are virtual transactions, it still needs to be reported to the tax authorities - thus a compliance dilemma. The second lies in the nature of the transaction: where tax knowledge is needed to identify whether the transaction is mining of virtual currencies that might be seen as a trade; or only as a method of payment with only normal tax consequences; or deemed to be the sale of an asset that will attract sales taxes.

\section{Conclusion and recommendations}

An individual's tax compliance is influenced by social and environmental factors that vary in different contexts. It is argued that specific tax knowledge is needed by individuals to effectively comply with their tax obligations in the digital economy. To this end, the elements of general, procedural and legal tax knowledge, as identified by the framework proposed by Bornman and Ramutumbu (2019), were used in this article.

The first objective of this study was to identify the tax knowledge requirements of individuals functioning in the digital economy and to categorise these requirements as general, procedural or legal. Our findings suggest that there are unique tax knowledge requirements in the digital economy. To be 'tax-knowledgeable', one needs to be aware of these challenges to make informed decisions concerning one's tax obligations. Furthermore, in terms of the digitalisation of interactions between people, organisations and governments, it was argued that being skilled in ICT

TABLE 1: Risks identified with respect to tax knowledge requirements for the digital economy.

\begin{tabular}{|c|c|}
\hline Knowledge requirement & Risk identified \\
\hline \multicolumn{2}{|l|}{ General } \\
\hline Who is liable for taxes? & $\begin{array}{l}\text { Lack of awareness that taxes should be paid } \\
\text { Perception that transactions are private and } \\
\text { not subject to tax } \\
\text { Uncertainty on how transactions should be reported }\end{array}$ \\
\hline \multicolumn{2}{|l|}{ Procedural } \\
\hline $\begin{array}{l}\text { Interaction between taxpayer } \\
\text { andtax authority }\end{array}$ & $\begin{array}{l}\text { Lack of ICT skills } \\
\text { Insufficient reading and writing skills } \\
\text { Fear of mistakes and/or fraud }\end{array}$ \\
\hline Digital record-keeping & $\begin{array}{l}\text { Lack of digital competence that could result in: } \\
\text { - records lost or destroyed, or not kept at all } \\
\text { the risk that records cannot be reproduced } \\
\text { if required }\end{array}$ \\
\hline \multicolumn{2}{|l|}{ Legal } \\
\hline Sharing economy & $\begin{array}{l}\text { Individuals may be unsure of their tax status } \\
\text { Risk of over-deductibility of expenses } \\
\text { Taxes collected (sometimes in cash) may not } \\
\text { be paid over to tax authorities }\end{array}$ \\
\hline $\begin{array}{l}\text { Provision of digital goods } \\
\text { and services }\end{array}$ & $\begin{array}{l}\text { Uncertainty on where and how transactions } \\
\text { are taxed } \\
\text { Incorrect tax treatment of expenses and } \\
\text { capital assets } \\
\text { Unawareness of double tax and possible remedies }\end{array}$ \\
\hline Virtual currencies & $\begin{array}{l}\text { Lack of understanding of compliance requirements } \\
\text { Incorrect identification of nature of transactions }\end{array}$ \\
\hline
\end{tabular}

ICT, information and communication technologies. might enhance effective interaction between taxpayer and tax authority.

The second objective was to point out risk areas in terms of knowledge requirements that may impede tax compliance among individual taxpayers. Taxpayers and tax authorities alike should take note of the risk areas identified in each knowledge area (general, procedural and legal). Our findings are summarised in Table 1.

Tax authorities will need to devise strategies to deal with tax on transactions in the digital economy, and indeed, many tax authorities have already implemented creative solutions to address these compliance risks. This study's contribution lies in the identification of risks in the different categories of taxpayers' knowledge that may cause taxpayers functioning in the digital economy to be non-compliant. It is proposed that further research build on the findings of this study to identify additional knowledge requirements in the digital economy and also investigate possible strategies to address taxpayers' knowledge deficits.

\section{Acknowledgements Competing interests}

The authors declare that they have no financial or personal relationships that may have inappropriately influenced them in writing this article.

\section{Authors' contributions}

M.B. and M.W. were responsible for the conceptualisation, literature review, data collection, analysis and interpretation of results.

\section{Ethical considerations}

This article followed all ethical standards for a research without direct contact with human or animal subjects.

\section{Funding information}

This research received no specific grant from any funding agency in the public, commercial or not-for-profit sectors.

\section{Data availability statement}

Data sharing is not applicable to this article as no new data were created or analysed in this study.

\section{Disclaimer}

The views and opinions expressed in this article are those of the authors and do not necessarily reflect the official position of the University of Johannesburg.

\section{References}

Akins, B.W., Chapman, J.L. \& Gordon, J.L., 2014, 'A whole new world: Income tax considerations of the Bitcoin economy', Pittsburgh Tax Review 12(1), 25-56. https://doi.org/10.5195/TAXREVIEW.2014.32 
Alakam, J., 2013, Nigeria: Firs's new drama series harps on tax compliance, viewed 16 May 2019, from https://allafrica.com/stories/201308051996.html.

Ali, A. \& Ahmad, N., 2014, 'Trust and tax compliance among Malaysian working youth', International Journal of Public Administration 37(7), 389-396. https://doi.org/10. 1080/01900692.2013.858353

Andreas \& Savitri, E., 2015, 'The effect of tax socialization, tax knowledge, expediency of tax ID number and service quality on taxpayers compliance with taxpayers awareness as mediating variables', Procedia - Social and Behavioral Sciences 211 163-169. https://doi.org/10.1016/j.sbspro.2015.11.024

Babu, R., n.d., The digital economy: Promise and peril in the age of networked, viewed 09 March 2018, from https://docplayer.net/865328-The-digital-economy-promiseand-peril-in-the-age-of-networked-intelligence-by-don-tapscott-reviewed-byrupali-babu.html.

Bal, A., 2015, 'How to tax Bitcoin', in D.L.K. Chuen (ed.), Handbook of digital currency Bitcoin, innovation, financial instruments and big data, pp. 267-282, Academic Press, Singapore.

Basu, S., 2001, 'Taxation of electronic commerce', Journal of Information, Law and Technology 2, viewed 08 March 2018, from http://elj.warwick.ac.uk/jilt/01-2/ basu1.html.

Bornman, M. \& Ramutumbu, P., 2019, 'A conceptual framework of taxpayer knowledge', Meditari Accountancy Research 27(6), 823-839.

Bornman, M. \& Wessels, J.J., 2019, 'The tax compliance decision of the individual in business in the sharing economy', e-Journal of Tax Research 16(3), 425-239.

Buehler, A., 1940, 'The tax system and tax consciousness', The Bulletin of the National Tax Association XXV(8), 237-246.

Carlsson, B., 2004, 'The digital economy: What is new and what is not?' Sciencedirect 15(3), 245-264, viewed 08 March 2018, from https://www.sciencedirect.com/ science/article/pii/S0954349X04000165.

Chen, J.V., Jubilado, R.J., Capistrano, E.P. \& Yen, D.C., 2015, 'Factors affecting online tax filing - An application of the IS Success Model and trust theory', Computers in Human Behavior 43, 251-262. https://doi.org/10.1016/j.chb.2014.11.017

Cockfield, A.J., 2002, 'The law and economics of digital taxation: Challenges to traditional tax laws and principles', International Bureau of Fiscal Documentation Tokyo, Keio University, 6-7 June 2002, viewed 09 March 2018, from http://post. queensu.ca/ ac24/TheLawEconDigitalTax.pdf.

Cullis, J.G. \& Lewis, A., 1997, 'Why people pay taxes: From a conventional economic model to a model of social convention', Journal of Economic Psychology 18(2-3) 305-321. https://doi.org/10.1016/S0167-4870(97)00010-X

Cvrlje, D., 2015, 'Tax literacy as an instrument of combating and overcoming tax system complexity, low tax morale and tax non-compliance', The Macrotheme Review 4(3), 156-167.

De Wit, K., Heerwegh, D. \& Verhoeven, J., 2014, 'Can openness to ICT and scientific research predict the ICT skills and ICT use of bachelor's students?', Computers and Education 78, 397-413. https://doi.org/10.1016/j.compedu.2014.07.003

Deards, K., 2017, 'The sharing economy', The Tax Specialist 20(5), 249-263.

Eriksen, K. \& Fallan, L., 1996, 'Tax knowledge and attitudes towards taxation: A report on a Quasi experiment', Journal of Economic Psychology 17(3), 387-402. https:// doi.org/10.1016/0167-4870(96)00015-3

Faizan, M., 2018, Taxpayers outreach programme to promote culture of tax compliance: Member Fate Nausheen Amjad, viewed 16 May 2019, from http:// www.customstoday.com. pk/taxpayers-outreach-program-to-promote-culture-of www.customstoday.com.pk/taxpayers-outreach-program-to-promote-cult
trust-and-shared-responsibility-member-fate-nausheen-javaid-amjad/.

Frenken, K. \& Schor, J., 2017, 'Putting the sharing economy into perspective', Environmental Innovation and Societal Transitions 23, 3-10. https://doi. org/10.1016/j.eist.2017.01.003

Gaber, S. \& Gruevski, I., 2018, 'The influence of tax culture in improving the tax compliance', Journal of Economics 3(2), 80-88.

Goncalves, G., Oliveira, T. \& Cruz-Jesus, F., 2018, 'Understanding individual-leve digital divide: Evidence of an African country', Computers in Human Behavior 87, 276-291. https://doi.org/10.1016/j.chb.2018.05.039

Haltiwanger, J. \& Jarmin, R.S., 2002, Understanding the digital economy: Data, tools and research, Massachusetts Institute of Technology Press, Cambridge, MA, viewed 08 March 2018, from https://books.google.co.za/books?hl=en\&lr=\&id=dpf2hL6E-GcC \&oi=fnd\&pg=PA1\&dq=digital+economy\&ots=sVsz8iUl6I\&sig=nIZKydctUR5ligopTim wyZaLQdl\#v=onepage \&q=digital\%20economy\&f=false.

Hastuti, R., 2014, 'Tax awareness and tax education: A perception of potentia taxpayers', International Journal of Business, Economics and Law 5(1), 83-91.

Hojeghan, S.B. \& Esfangareh, A.N., 2011, 'Digital economy and tourism impacts, influences and challenges', Procedia - Social and Behavioral Sciences 19, 308-316, viewed 08 March 2018, from https://www.sciencedirect.com/science/article/pii/ S1877042811012511.

Income Tax Department, 2019, Income Tax Department, Government of India: Publicity campaigns, viewed 16 May 2019, from https://www.incometaxindia.gov. in/Pages/publicity-campaign.aspx?year=2019.

Kamil, N.I., 2015, 'The effect of taxpayer awareness, knowledge, tax penalties and tax authorities services on the tax compliance: Survey on the individual taxpayers at Jabodetanel and Bandung', Research Journal of Finance and Accounting 6(2), 104-111.

Kamleitner, B., Korunka, C. \& Kirchler, E., 2012, 'Tax compliance of small business owners: A review', International Journal of Entrepreneurial Behavior \& Research 18(3), 330-351. https://doi.org/10.1108/13552551211227710

Kirchler, E., 2007, The economic psychology of tax behaviour, New York, Cambridge University Press.
Lai, M., Zalilawati, Y., Amran, M. \& Choong, K., 2013, 'Quest for tax education in nonaccounting curriculum: A Malaysian study', Asian Social Science 9(2), 154-162. https://doi.org/10.5539/ass.v9n2p154

Macklin, A., 2008, 'A PBL approach for teaching complex information and communication technology (ICT) skills in higher education', Community \& Junior College Libraries 14(4), 233-249. https://doi.org/10.1080/02763910802336381

Mauritius Revenue Authority, n.d., We're on Twitter - Follow us, viewed 24 May 2019 from http://www.mra.mu/index.php/29-home/media-centre/149-twitter.

Mbatha, M., 2015, Match tax-collecting vigour with spending sense, viewed 24 May 2019, from https://www.news24.com/Columnists/GuestColumn/Match-taxcollecting-vigour-with-spending-sense-20150608-3.

Mukhlis, I., Utomo, S.H. \& Soesetio, Y., 2015, 'The role of taxation education on taxation knowledge and its effect on tax fairness as well as tax compliance on handicraft SMEs sectors in Indonesia', International Journal of Financial Research 6(4), 161-169. https://doi.org/10.5430/ijfr.v6n4p161

Nellen, A., 2015, 'Taxation and today's digital economy', Journal of Tax Practice and Procedure, April - May 2015, 27-37.

Nickitas, D.M. (ed.), 2019, 'Nursing economic\$', in Editorial: First-face communication: Is digital technology impacting leadership communication effectiveness?, pp. 65-66, Jannetti Publications Inc, Sewell, NJ.

Niemirowski, P., Baldwin, S. \& Wearing, A.J., 2003, 'Tax related behaviours, beliefs, attitudes and values and taxpayer compliance in Australia', Journal of Australian Taxation 6(1), 132-165.

Oladipupo, A.O. \& Obazee, U., 2016, 'Tax knowledge, penalties and tax compliance in small and medium scale enterprises in Nigeria', iBusiness 8(1), 1-9. https://doi. org/10.4236/ib.2016.81001

Olivier, L. \& Honiball, M., 2011, International tax: A South African perspective, Cape Town, SiberInk.

Organisation for Economic Co-operation and Development (OECD), 2015a, Building tax culture, compliance and citizenship: A global source book on taxpayer tax culture, compliance
education, Paris, OECD.

Organisation for Economic Co-operation and Development (OECD), 2015b, Tax administration 2015: Comparative information on OECD and other advanced and emerging economies, Paris, OECD.

Organisation for Economic Cooperation and Development (OECD), 2015c, OECD/G20 Base erosion and profit shifting project: 2015 final reports, viewed 08 March 2018, from http://www.oecd.org/ctp/beps-reports-2015-executive-summaries.pdf.

Organisation for Economic Co-operation and Development (OECD), 2016, Skills for a digital world, 2016 Ministerial meeting on the Digital Economy, OECD, viewed 08 March 2018, from http://www.oecd-ilibrary.org/science-and-technology/skillsfor-a-digital-world_5jlwz83z3wnw-en.

Organisation for Economic Co-operation and Development (OECD), 2017a, Tax challenges of digitalisation, Paris, OECD.

Organisation for Economic Co-operation and Development (OECD), 2017b, Tax administration 2017. Comparative information on OECD and other advanced and
emerging economies, viewed 30 May 2018, from http://www.oecd.org/ctp/ emerging economies, viewed 30 May 2018, from
administration/tax-administration-23077727.htm.

Organisation for Economic Co-operation and Development (OECD), 2019, The sharing and Gig economy: Effective taxation of platform sellers, Forum on Tax Administration, OECD Publishing, Paris, viewed 24 June 2019, from https://read. oecd-ilibrary.org/taxation/the-sharin

Palil, M.R., 2010, 'Tax knowledge and tax compliance determinants in self assessment system in Malaysia', Doctoral thesis, University of Birmingham, Birmingham.

Palil, M.R. \& Mustapa, A.F., 2011, 'Factors affecting tax compliance behaviour in self assessment system', African Journal of Business Management 5(33), 12864-12872. http://www.academicjournals.org/AJBM DOI: 10.5897/AJBM11.1742

Rothenberg, J., 1995, 'Ensuring the longevity of digital documents', Scientific American 272(1), 42-47, viewed 08 March 2018, from http://0-www.jstor.org.ujlink.uj. ac.za/stable/24980135.

Rwanda Revenue Authority, 2018, Annual Activity report 2017/2018, viewed 16 May 2019, from https://www.rra.gov.rw/fileadmin/user_upload/rra_annual_activity report_2017-18.pdf.

Rwanda Revenue Authority, 2019, Students learn taxes as global money week goes on viewed 16 May 2019, from https://www.rra.gov.rw/index.php?id=286\&tx_news pi $1 \% 5 \mathrm{Bnews} \% 5 \mathrm{D}=181 \&$ tx_news_pi $1 \% 5 \mathrm{~B}$ controller $\% 5 \mathrm{D}=$ News\&tx_news_pi $1 \% \overline{5}$ Baction\%5D=detail\&cHash=16bec3a578903e30bf67a504d465706f

Saad, N., 2014, 'Tax knowledge, tax complexity and tax compliance: Taxpayers' view', Procedia - Social and Behavioral Sciences 109(8), 1069-1075. https://doi. org/10.1016/j.sbspro.2013.12.590

Sandhu, J., Damodaran, L. \& Ramondt, L., 2013, 'ICT skills acquisition by older people: Motivations for learning and barriers to progression', International Journal of Education and Ageing 3(1), 95-114.

Saunders, M., Lewis, P. \& Thornhill, A., 2012, Research methods for business students, Pearson Education, Essex.

Sharp, L., 2015, SARS' threatening TV ads are counter-productive, viewed 16 May 2019, from http://www.acts.co.za/news/blog/2015/01/sars-threatening-tv-adsare-counterproductive.

South African Revenue Service (SARS), 2017, Annual Report 2016-2017, viewed 14 March 2018, from http://www.sars.gov.za/About/Pages/Annual-Reports-andStrategic-Plans.aspx.

South African Revenue Service (SARS), 2018, Record keeping, viewed 14 March 2018, from http://www.sars.gov.za/clientsegments/businesses/smallbusinesses/ stratingbusiness/record-keeping/Pages/default.aspx. 
Switzer, J.S. \& Switzer, R.V., 2014, 'Taxation of virtual world economies: A review of the current status', Journal of Virtual Worlds Research: Lantern Part 1/2 7(1), 1-16. https://doi.org/10.4101/jvwr.v7i1.6292

Tallaha, A.M., Shukor, Z.A. \& Hassan, N., 2014, 'Factors influencing e filing usage among Malaysian taxpayers: Does tax knowledge matter?', Jurnal Pengurusan 40 91-101. https://doi.org/10.17576/pengurusan-2014-40-08

Thorne, D. \& Quinn, F.F., 2017, 'Supplier resources in the sharing economy: Three regulatory concerns', Journal of Marketing Channels 24(1-2), 73-83. https://doi. org/10.1080/1046669X.2017.1347003

Vuori, V., Helander, N. \& Okkonen, J., 2019, 'Digitalization in knowledge work: The dream of enhanced performance', Cognition, Technology \& Work 21, 237-252. https://doi.org/10.1007/s10111-018-0501-3
Wilson, R.M., Abraham, A. \& Mason, C.L., 2014, The Routledge companion to accounting education, New York, Routledge.

World Bank, 2015, World Development Report 2015, Washington, DC, [S.p.].

Wosskow, D., 2014, Unlocking the sharing economy: An independent review, viewed 08 March 2018, from https://assets.publishing.service.gov.uk/government/ uploads/system/uploads/attachment_data/file/378291/bis-14-1227-unlockingthe-sharing-economy-an-independent-review.pdf.

Zale, K., 2016, 'When everything is small: The regulatory challenge of scale in the sharing economy', San Diego Law Review 53, 949-1016.

Zietsman, M.E., 2017, 'Assessing the normal tax implications of a home swap for a resident owning property in South Africa', Master's thesis, University of Stellenbosch, Stellenbosch. 